\title{
Survey for Newcastle Disease Virus Antibodies in Local Chickens, Ducks and Pigeons in Makurdi, Nigeria
}

\author{
Abah Helen Owoya ${ }^{*}$, Ochola Peter Friday, Ishaya Victor \\ Department of Veterinary Medicine, College of Veterinary Medicine, University of Agriculture Makurdi, Makurdi, Benue State, Nigeria \\ Email address: \\ helenabah505@gmail.com (Abah H. O.) \\ ${ }^{*}$ Corresponding author

\section{To cite this article:} \\ Abah Helen Owoya, Ochola Peter Friday, Ishaya Victor. Survey for Newcastle Disease Virus Antibodies in Local Chickens, Ducks and \\ Pigeons in Makurdi, Nigeria. Animal and Veterinary Sciences. Vol. 8, No. 3, 2020, pp. 55-59. doi: 10.11648/j.avs.20200803.12
}

Received: March 26, 2020; Accepted: April 17, 2020; Published: June 17, 2020

\begin{abstract}
This study aimed to determine the seroprevalence of Newcastle disease (ND) among some local poultry species from live bird markets (LBM) and households in Makurdi Benue State, Nigeria. A total of 543 (300 local chickens, 199 pigeons and 44 ducks) sera samples were collected between October 2018 to April 2019. Sera samples were tested using Haemagglutination inhibition HI) test. The overall seroprevalence of Newcastle disease virus (NDV) antibodies was $9.9 \%$ (54/543). The prevalence of antibodies to ND was found to be higher in ducks $20.5 \%(9 / 44)$, followed by local chickens $10 \%$ $(30 / 300)$ and pigeons $7.5 \%(15 / 199)$ respectively. There was statistical significant association $(\mathrm{P}=0.000817)$ between location of sampling of local poultry and seropositivity for ND. Also there was a statistical significant association $(\mathrm{P}=0.0348)$ between species of local poultry and ND antibody titre. This study revealed that local chickens, ducks and pigeons in Makurdi could play significant role in the epidemiology and transmission of ND to susceptible commercial exotic birds or other local poultry species especially when reared in close proximity. The study concluded that the prevalence of ND antibodies indicated the presence of the virus among the population and ducks and pigeons could be reservoirs and carriers for NDV. Vaccination campaign should be organized for local poultry species for the control of ND in the study area.
\end{abstract}

Keywords: Newcastle Disease Virus, Antibody Titre, Local Poultry, Haemagglutination Inhibition Test, Live Bird Market

\section{Introduction}

Newcastle disease (ND) is a major viral disease of economic importance in poultry and rated as one of the greatest constraints to the development of rural poultry production in Nigeria and in most developing countries [1]. The disease is caused by virulent strains of avian paramyxovirus type 1 (AMPV-1) serotype of the genus Avulavirus belonging to the family Paramyxoviridae. The paramyxoviruses isolated from avian species have been classified by serological testing and phylogenetic analysis into ten subtypes designated APMV-1 to APMV-10 [2]. According to the severity level of the outbreak in chicken, Newcastle disease virus (NDV) was classified into three pathotypes namely: lentogenic, mesogenic, and velogenic strains. Velogenic strain is distinguished into neurotropic and viscerotropic form [3]. The disease is characterized by gastrointestinal and respiratory signs often associated with nervous disorders and high mortality (up to $100 \%$ ). Several species of birds are affected by ND with chickens and turkeys being readily susceptible. Over 250 species of birds have been reported to be susceptible to NDV as a result of natural or experimental infections, and it is likely that many more susceptible species exist but have not yet been identified [4]. In domestic pigeons, NDV is of high economic importance and worldwide occurrence has been reported including India $[5,6]$. The ability of non-poultry avian species to introduce and disseminate NDV has been previously established, and feral pigeons (Columba spp.) have been implicated as carriers of NDV [7,8]. The first report of ND in Nigeria was in 1952 [9], thereafter several cases have been reported in commercial, rural scavenging, captive and free-living wild birds making it enzootic across the entire country [10-13]. Serological evidence of ND infection in pigeons in Nigeria has been reported [14]. The poultry industry in Nigeria offer the quickest supply of animal protein to man in form of high quality eggs and meat and provides comparatively faster return to investment than 
cattle, small ruminants and pigs [15]. As practiced in most developing economies, poultry production systems are generally categorized into two major groups, namely; subsistent (free-range) and commercial poultry [16]. In Nigeria free range poultry accounts for over $80 \%$ of the poultry population [17]. The sustainability of this subsector is being threatened as a result of incessant outbreaks of ND in unvaccinated flocks and sporadically in vaccinated flocks [18].

Assessment of economic impact due to ND is not only limited to high mortality recorded from the outbreaks and the cost of control measures but also on the trade restrictions placed on the localities where outbreaks have been reported $[19,20]$. Economic and financial losses as a result of incessant ND outbreaks in Nigeria are not being regularly quantified. An estimated 78,526 outbreaks of the disease were reported in 2008 across Nigeria with an estimated financial burden of 8.9 billion naira for local chickens alone [21]. The free-range chickens have been implicated in harbouring velogenic strains of the virus which have been considered a threat to the commercial poultry [10]. Available information on ND and its extent of distribution in local poultry species especially pigeons and ducks in Makurdi are scanty. This present study therefore aimed at detecting antibodies to Newcastle disease virus infection from some local poultry species sampled from households and major live bird markets in Makurdi, Benue State.

\section{Materials and Methods}

\subsection{Study Area}

The study was carried out in Makurdi the capital of Benue State, Nigeria. Makurdi is located in the North Eastern part of Benue State and lies on latitude $7^{0} 30^{\prime} \mathrm{N}$ and longitude $8^{0} 35 \mathrm{E}$. It is located within the flood plain of lower River Benue valley [22]. The physiographic characteristics span between $73-167 \mathrm{~m}$ above sea level. The town is divided by the River Benue into the North and South banks, connected by two bridges: the railway bridge and the dual carriage bridge [22]. The study locations were four live bird markets (LBMs) and households within Makurdi metropolis. The locations were; North bank market, Wadata market, Wurukum market, Modern market and birds also sampled from households in the same locations.

\subsection{Sampling Method and Sample Size}

Simple random and convenient sampling methods were used for survey locations. The sample size was calculated using the formula of Thrustfield [23] using 1.6\% anticipated prevalence obtained for ND virus in ducks in Lafia, Nasarawa State by [24], in pigeons $48.7 \%$ by [25] in Zaria, Kaduna State and in local chickens $45.6 \%$ by [26] in Benue State. A total of 543 sera were collected.

\subsection{Collection of Blood}

Blood sample was collected from each bird after proper restraint with the use of a 21 gauge needle attached to a $5 \mathrm{ml}$ syringe to withdraw 1-2 $\mathrm{ml}$ of blood from the brachial vein. The blood collected was allowed to stand for two hours at room temperatures for clotting to occur and the serum decanted into a bijou bottle. The samples were then labeled and stored under ice then transported to the laboratory and kept at $-20^{\circ} \mathrm{C}$ until used.

\subsection{Detection of Newcastle Disease Antibodies}

The LaSota strain of NDV and antibody positive serum were obtained from the National Veterinary Research Institute (NVRI), Vom and used as positive antigen and control serum respectively. A $1 \%$ suspension of chicken red blood cells (RBC) was prepared and used as indicator in the haemagglutination (HA) and haemagglutination inhibition (HI) tests according to methods described in OIE protocol [27]. Sera with HI antibody titre $\geq 1 \log 2$ and $\geq 4 \log 2$ were considered positive and protective respectively based on OIE manual [27].

\subsection{Data Analysis}

The data obtained from serology was subjected to SPSS package version 16. Categorical variables were evaluated using Chi-square to check for independence. Values of $P<$ 0.05 were considered significant.

\section{Results}

An overall seroprevalence of $9.9 \%$ (54/543) was recorded among the different species of poultry examined. Out of the 300 local chicken sera sample tested $30(10 \%)$ were positive for ND antibodies, while out of 44 ducks and 199 pigeon sera tested $9(20.5 \%)$ and $15(7.5 \%)$ were positive for ND antibodies respectively. There was a statistical significant association $\mathrm{P} \leq 0.05\left(\mathrm{P}=0.0348 ; \mathrm{X}^{2}=6.715\right)$ between species of local poultry and ND antibody titre (Table 1).

The seroprevalence and distribution of ND antibody titre by Haemagglutination inhibition test showed that $80 \%$ of the ducks sampled had antibody titre between 1-3 $\log _{2}$ while $0 \%$ and $20.5 \%$ had antibody titre $\geq 4 \log _{2}$ and $\geq 7 \log _{2}$ respectively. In local chicken, $92 \%$ had antibody titre between $1-3 \log _{2}, 4 \%$ had antibody titre $\geq 4 \log _{2}$ and $\geq 7 \log _{2}$. A total of $91 \%$ had antibody titre between $1-3 \log _{2}, 2.4 \%$ had antibody titre of $\geq 4 \log _{2}$ and $6.4 \%$ had antibody titre $\geq 7 \log _{2}$ (Table 2 ).

Table 1. Prevalence of Newcastle Disease Virus Among Poultry Species in Makurdi, Benue state, Nigeria.

\begin{tabular}{lll}
\hline Poultry Species & No. of Sera Tested & (\%) Sera Positive \\
\hline Ducks & 44 & $9(20.5)$ \\
Pigeons & 199 & $15(7.5)$ \\
Local chickens & 300 & $30(10.0)$ \\
Total & 543 & $54(9.9)$ \\
\hline $\mathrm{P}=0.0348, \mathrm{X}^{2}=6.715$ & &
\end{tabular}


Table 2. Seroprevalence and distribution of Newcastle Disease antibody titre by haemagglutination inhibition (HI) test in poultry species in Makurdi, Benue state, Nigeria.

\begin{tabular}{llll}
\hline Species & \% of birds with HI titre 1-3 $\log _{\mathbf{2}}$ & $\mathbf{\% ~ o f ~ b i r d s ~ w i t h ~ H I ~ t i t r e ~} \geq \mathbf{4 L o g}_{\mathbf{2}} \mathbf{\% ~ o f ~ b i r d s ~ w i t h ~ H I ~ t i t r e ~} \geq \mathbf{7 L o g}_{\mathbf{2}}$ & $20.5(9 / 44)$ \\
\hline Duck & $80(35 / 44)$ & $0(0 / 44)$ & $7(14 / 199)$ \\
Pigeon & $93(184 / 199)$ & $0.5(1 / 199)$ & $4(12 / 300)$ \\
Local chicken & $92(276 / 300)$ & $4(12 / 300)$ & $6.4(35 / 543)$ \\
Total & $91(495 / 543)$ & $2.4(13 / 543)$ & \\
\hline
\end{tabular}

The distribution of antibody titre according to sampling locations revealed that live bird market had a higher seroprevalence $11.1 \%(23 / 207)$ than birds sampled from different households 9.2\% (31/336). Birds from LBM in North bank had seroprevalence of 3.1\% (1/32), Wadata LBM had 35\% (7/20), Modern Market had 14.3\% (10/70) and Wurukum LBM had 5.9\% (5/85). There was a statistically significance association ( $\mathrm{p}$-value $=0.000817, \mathrm{X}^{2}=18.914$ ) between location of sampling of local poultry and seroprevalence for ND (Table 3 ).

Table 3. Distribution of Newcastle disease antibody titre according to sampling locations in Makurdi, Benue state, Nigeria.

\begin{tabular}{llll}
\hline Location & No of samples & No of positive & Prevalence (\%) \\
\hline Northbank LBM & 32 & 1 & 3.1 \\
Wadata LBM & 20 & 7 & 35 \\
Modern market & 70 & 10 & 14.3 \\
Wurukum LBM & 85 & 5 & 5.9 \\
House hold & 336 & 31 & 9.2 \\
Total & 543 & 54 & 9.9 \\
\hline
\end{tabular}

$\mathrm{P}=0.000817, \mathrm{X}^{2}=18.914$

\section{Discussion}

The overall seroprevalence of Newcastle disease in the study area was $9.9 \%$. None of the birds sampled had a history of previous vaccination against ND. Antibodies detected may be a result of natural infection since vaccination of the local poultry is rarely undertaken in Nigeria [28]. The prevalence rate was higher in ducks $(20.5 \%)$ compared to chickens $(10 \%)$ and pigeons $(7.5 \%)$. Ducks are known carriers of the avirulent NDVs which may mutate to virulent ND virus strains [29]. Waterfowls such as ducks and geese may be infected but show few or no clinical signs even to the strains that are virulent to chickens [30]. The risk of NDVs transmission from ducks or water birds may be either through direct or indirect contact with poultry flocks such as contaminated feed and water or infection of wild bird species at common water sites and then transmission of the infection into poultry flocks [31]. This suggest that ducks in the study area should be considered as an important factor in the epidemiology of the disease. The seroprevalence recorded in local chickens in this study was $10 \%$. This result is lower than the prevalence of $46 \%$ reported in village chickens in Borno State [32] and 54.67\% in Nasarawa State [24] among local scavenging chickens kept under traditional management system. This variation could be due to differences in study settings or by exposure to mild virus strains that induced immunity but did not kill many chickens. Also, seroprevalence rate of ND antibodies could be attributed to factors such as the management system in traditional production where birds of different ages and species scavenge and interact together which may serve as a stress factor and favour infection [33]. The seroprevalence of 7.5\% recorded in pigeons in this study is lower than $48.7 \%$ reported in Gombe State, Nigeria [34]. Although there was no report of clinical outbreak of ND in domestic pigeons in Nigeria, there has only been serological evidence of ND infections in pigeons in Nigeria [14]. Pigeons can be infected with ND virus and may therefore serve as reservoir of ND virus for more susceptible poultry species [25]. Feedstuffs contaminated with feaces of feral pigeons infected by pigeon paramyxovirus (PPMV) were considered to be sources of infection in many outbreaks, since pigeons easily come in contact with free-range birds. Thus, they may disseminate NDV among many different avian species [35]. There was an outbreak of ND in UK due to contamination of poultry feed with faeces of pigeons [36]. This implies that ND infected pigeons can play a significant role in transboundary transmission of the disease since they can fly several miles across regions. The distribution of the percentage of birds with HI protective antibody titre level $\left(4 \log _{2}\right)$ was low compared with birds with detectable antibody level. This finding of NDV antibodies in these apparently healthy birds suggests that the birds have either recovered from clinical ND or are having subclinical infections [37]. This also implies that a greater proportion of the local poultry specie in the study area (91\%) will be more vulnerable to challenge with a virulent strain of NDV if there is an outbreak of the disease because of low level of antibody against ND. Different antibody titre cutoff values has been used by different researchers for the interpretation of HI test results. This could be another reason for variation between studies, some authors considered an $\mathrm{HI}$ antibody titer $\geq 1 \log 2$ as positive $[38,39]$, whereas others used cut-off titers of $\geq 3 \log 2$ $[40,41]$. However, the present study used $\geq 4 \log 2$ as HI protective antibody level (OIE) [42], which is similar with the cutoff values used by Gutierrez-Ruiz [43].

The present study revealed that the origin of the birds was significantly associated with ND seropositivity $(\mathrm{p}<0.05)$. Birds from Live bird markets had a higher prevalence rate when compared with those sampled from households. This may be due to the fact that live bird markets contribute to the persistence and spread of ND virus $[44,26]$. These birds are exposed to birds from multiple sources having a higher tendency of circulating the virus and may serve as a source of infection to house hold chickens when introduced [45]. Other studies conducted on village chickens at live bird markets in 
Nigeria by $[46,44,47])$ showed $35.8 \%, 25.5 \%$ and $65.1 \%$ seroprevalent rates respectively. Furthermore, contact of birds of one rural area with those of another rural area through gift and sale of rural chickens which in some cases are diseased or carriers of some diseases may facilitate the spread NDV among flocks [48].

\section{Conclusion}

The findings of this research work revealed the presence of antibodies against ND Virus in sera of apparently healthy local chickens, ducks and pigeons in Makurdi, Benue State Nigeria. The overall seroprevalence in ducks (20.5\%) was higher than that of the local chickens $(10 \%)$ and pigeons (7.5\%) respectively. This finding is not in agreement with the general believe that local chickens usually have a higher value of NDV antibody than other domestic poultry species. Local poultry could play a significant role in the epidemiology and transmission of the NDV to exotic and commercial poultry species especially when reared in close proximity. It is therefore recommended that routine vaccination programmes against ND should include other poultry species such as ducks and pigeons to prevent disease outbreak that could lead to economic loss in the poultry industry.

\section{Acknowledgements}

The authors are grateful to all the local poultry farmers and live bird market sellers for their cooperation during sample collection. We also thank staff of the Regional Laboratory, National Veterinary Research Institute, Vom for their technical support.

\section{References}

[1] Anosa GN, Adene DF. Comparative tissue reactivity of lentogenic strains of Newcastle disease vaccine in Nigeria. Nig. Vet. J. 2007; 28 (3): 6-10.

[2] Miller PJ, Afonso CL, Spackman E, Scott MA, Pedersen JC. Evidence for a new Avian Paramyxovirus Serotype-10 detected in Rockhopper Penguins from the Falkland Islands. J. Virol 2010; 84: 11496-11504.

[3] Aldous EW, Alexander DJ, 2001. Detection and differentiation of Newcastle disease virus avian paramyxovirus type 1 . Avian Pathol 2001; 30 (2): 117-128.

[4] James AA, Samuel M, Olatunde H, Olabode BJ, Adah GR, Okoh M, Echioda O, Alalade DI. Seroprevalence of Newcastle disease virus antibodies in local and exotic chickens in Gwagwalada. Nig. J. Vet. Med. Anim. Hlth 2016; 8 (11) 193198.

[5] Kataria JM, Dhama K, Rahul S, Singh SD, Sah RL. Occurrence of Newcastle disease in pigeons in India and immune response following immunization with inactivated homologous and heterologous paramyxovirus. Indian $\mathrm{J}$. Comp. Microb. Immunol. Infect. Dis 2004; 25, 53-56.
[6] Naveen KA, Singh SD, Kataria JM, Barathidasan R, Dhama $\mathrm{K}$. Detection and differentiation of pigeon paramyxovirus serotype-1 (PPMV-1) isolates by RT-PCR and restriction enzyme analysis. Tropical Animal Health and Production 2013; 10: 01-06.

[7] Kapczynski DR, Wise MG, King DJ. Susceptibility and protection of naïve and vaccinated racing pigeons (Columba livia) against exotic Newcastle Disease Virus from the California 2002- 2003 outbreak. Avian Dis 2006; 50: 336341.

[8] Onapa MO, Christensen H, Mukiibi GM. A preliminary study of the role of ducks in the transmission of Newcastle disease virus to in-contact rural free-range chickens. Trop. Anim. Hlth Prod 2006; 38: 285-289.

[9] Hill HD, Davis OS, Wilde JE. Newcastle disease in Nigeria. Br. Vet. J 1953; 109: 381-5.

[10] Echeonwu GON, Iroegbu CU, Emeruwa AC. Recovery of velogenic Newcastle disease virus from dead and healthy free roaming birds in Nigeria. Avian Pathol 1993; 22: 383-7.

[11] Ibu JJ, Okoye E, Adulugba K, Chah S Shoyinka Salihu E. Prevalence of Newcastle disease virus in wild and captive birds in Central Nigeria. Int. J. Poult Sci 2009; 8: 574-8.

[12] Nwanta JA, Abdu PA, Ezema W. Epidemiology, challenges and prospects for control of Newcastle disease in village poultry in Nigeria. Worlds Poult Sci J 2008; 64: 119-27.

[13] Ojeh CK, Okoro HO. Isolation and characterisation of Newcastle disease virus strain in a feral dove (Stigmatopelia senegalensis) in Nigeria. Trop Anim Health Prod 1992; 24: 211.

[14] Oladele SB, Kazeem HM, Raji MA. Survey for antibodies to infections bursal disease, Newcastle disease and fowl pox in ducks, pigeons and guinea fowls in Zaria. Nigeria Vet. J. 1996; 1: 25-87.

[15] Matur BM, Dawam NN, Malann YD. Gastrointestinal helminth parasites of local and exotic chickens slaughtered in Gwagwalada, Abuja (FCT), Nigeria. New York Sci. J. 2010; 3 (5): 96-99.

[16] Adeyemo AA, Onikoyi MP. Prospects and challenges of large scale commercial poultry production in Nigeria. Agric J. 2012; 7: 388-93.

[17] Adene D, Oguntade A. The structure and importance of the commercial and village based poultry industry in Nigeria. Nigerian Poultry Sector Report. Rome; 2006.

[18] Solomon P, Abolnik C, Joannis TM, Bisschop S. Virulent Newcastle disease virus in Nigeria: identification of a new clade of sub-lineage $5 \mathrm{f}$ from livebird markets. Virus Genes 2012; 44: 98-103.

[19] Aldous EW, Alexander DJ. Newcastle disease in pheasants (Phasianus colchicus): a review. Vet J. 2008; 175: 181-5.

[20] Ganar K, Das M, Sinha S, Kumar S. Newcastle disease virus: current status and our understanding. Virus Res 2014; 184: $71-81$.

[21] Fadiga M, Jost C, Ihedioha J. Financial costs of disease burden, morbidity and mortality from priority livestock diseases in Nigeria. Disease burden and cost-benefit analysis of targeted interventions. ILRI Res. Rep. Nairobi, Kenya; 2013, 1-84. 
[22] Tyubee BT. The influence of ENSO and North Atlantic sea surface temperature anomaly (SSTA) on extreme rainfall events in Makurdi, Nigeria. Meteorol. Climate Science 2009; 7: 28-33.

[23] Thrustfield M. Veterinary Epidemiology. $2^{\text {nd }}$ Edition 2005; Blackwell publishing Ltd, UK.

[24] Salihu AE, Chukwuedo AA, Echeonwu GON. Seroprevalence of Newcastle disease virus infection in rural household birds in Lafia, Akwanga and Keffi Metropolis, Nasarawa State Nigeria. Int. J. Agric. Sci 2012; 2 (2): 109-112.

[25] Sa'idu, L, Tekdek LB, Abdu PA. Prevalence of Newcastle disease antibodies in domestic and semi domestic birds in Zaria, Nigeria. Veterinarski Arhiv 2004; 74 (4): 309-317.

[26] Abah HO, Abdu PA, Assam A. Seroprevalence of Newcastle Disease Virus in Chickens in Six Local Government Areas of Benue State, Nigeria. Int. J. Poult. Sci 2016; 15 (11): 454-458.

[27] Office International des Epizootics (OIE). Manual of Diagnostic Tests and Vaccines for Terrestrial Animals 2009, 2.3.14

[28] Abdu PA, Abdullahi SU, Adesiyun AA, Ezeokoli CD Challenge study on infectious bursal disease in chicks derived from vaccinated hens, Trop. Anim. Hlth. Prd 1987; 19 (1): 4752 .

[29] Alexander DJ. Newcastle disease. The Gordon Memorial Lecture: British Poultry Science 2001; 42 (1): 5-22.

[30] Liu H, Wang Z, Wu Y, Zheng D, Sun C, Bi D, Zuo Y, Xu T. Molecular epidemiology and analysis of Newcastle disease virus isolated in China in 2005. J. Virol. Methods 2007; 140: 206-211.

[31] Ameji NO, Sa'idu L, Abdu PA. Newcastle disease antibodies in apparently healthy wildbirds in Kogi state, Nigeria. Research Journal of Veterinary Sciences 2015; 8 (3): 52-60.

[32] EL-Yuguda AD, Ngulde IS, Abubakar MB, Baba SS. Village chicken health, management and production indices in selected villages of Borno State. Niger. Family Poult. J. 2007; 17: $1-2$.

[33] Minda AG, Kemal KE, Gezahegne MK. Newcastle disease: Seroprevalence and associated risk factors in backyard and small scale chicken producer farms in Agarfa and Sinana Districts of Bale Zone, Ethiopia. J. Vet. Med. Anim. Hlth 2016; 8 (8): 99-106.

[34] Lawal JR, El-Yuguda AD, Ibrahim UI. Survey on Prevalence of Newcastle Disease Antibodies in Village Poultry at Live Birds Markets in Gombe, Nigeria. J Anim Sci Livest Prod. 2016, 1: 1 .

[35] Toro H, Hoerr FJ, Farmer K, Dykstra CC, Roberts SR, Perdue M. Pigeon Paramyxovirus: Association with Common Avian Pathogens in Chickens and Serologic Survey in Wild Birds. Avian Dis 2005; 49: 92-98.
[36] Okeame, AN, Folorunsho AD, Falayi BA. An outbreak of Newcastle disease in guinea fowls (Numida meleagris) in Nigeria Bull Amin Hlth Prod Afr 1988; 36.176-17.

[37] Bell, J. G and S. Mouloudi, 1988. A reservoir of virulent Newcastle disease virus in village chicken flocks, Preventive Vet. Med. 6 (1): 37-42.

[38] Bouzari M, Mousavi Morekani R. Seroepidemiology of Newcastle disease in domestic village chickens of plain areas of Isfahan province, central India. Ind. J. Vet. Res 2006; 7: 8084

[39] Biswas PK, Barua H, Uddin GMN, Biswas D, Ahad A, Debnath NC. Serosurvey of five viruses in chickens on smallholdings in Bangladesh. Prev. Vet. Med 2009; 88: 67-71.

[40] Tadesse S, Ashenafi H, Zeleke A. Seroprevalence study of Newcastle disease in local chickens in Central Ethiopia. Int. J. App. Res. Vet. Med 2005; 3 (1): 25-29.

[41] Zeleke A, Sori T, Gelagaye E, Ayelet G. Newcastle disease in village chickens in the southern and rift valley districts in Ethiopia. Int. J. Poult. Sci 2005; 7: 508-510.

[42] Office International Des Epizootics (OIE). Newcastle disease. In: Manual of diagnostic tests and vaccines for terrestrial animals 2012; pp 555-574

[43] Gutierrez-Ruiz EJ, Ramirez-Cruz GT, Camara Gamboa EI, Alexander DJ, Gough REA. Serological survey for avian infectious bronchitis virus and Newcastle disease virus antibodies in backyard (free-range) village chickens in Mexico. Trop. Anim. Health Prod 2000; 32: 381-390.

[44] Jibril AH, Umoh JU, Kabir J, Saidu L, Magaji AA. Newcastle disease in local chickens of live bird markets and households in Zamfara State, Nigeria. Int. Scholarly Research Notices: Epidemiology 2014; pp: 1-4.

[45] Killian ML. National Veterinary Services laboratories avian influenza and Newcastle disease diagnostics report. In: Proceedings of the 113th Annual Meeting of the United States Animal Health Association 2009; pp. 590-593, 2009.

[46] Chollom SC, Emerhirhi FT, Akwaowo EE, Ogbaji JU, Fyaktu EJ. Implication of Newcastle disease virus in local chickens at Live Bird Markets in Jos. Nigeria Int. J. Cur Res 2013; 5: 2872-2874.

[47] Eze IA, Ike AC. The Serological Status for Newcastle Disease in Local Chickens of Live bird Markets and households in Nsukka, Enugu State, Nigeria. Niger J Microbiol 2015; 29: 3096-3104.

[48] Musa U, Abdu PA, Dafwang II, Umoh JU, Sa'idu L, Mera UM, Edache JA. Seroprevalence, seasonal occurrence and clinical manifestation of Newcastle disease in rural household chickens in Plateau State, Nigeria. Int. J. Poult. Sci 2009; 8 (2): 200-204. 